\title{
HUBUNGAN KARAKTERISTIK INDIVIDU TERHADAP PERILAKU MENGENAI PANDEMI COVID-19 DI DESA GULINGAN, MENGWI, BALI
}

1| Made Sindy Astri Pratiwi, 2|Made Violin Weda Yani, 3| Agus Indra Yudhistira Diva Putra, 4| I Wayan Gita Mardiana, 5| I Komang Ari Adnyana, 6| Nyoman Manik Mas Genitri Putri, 7| Ni Putu Sri Widi Adnyani Karang, dan 8| I Putu Yudhi Setiawan

Email : sindyastri@student.unud.ac.id

ABSTRACT
Covid-19 is a contagious infectious disease that continues to increase as a global pandemic.
Everyone from all individual characteristic must have good behaviors to prevent Covid-19
as a pandemic. Until now, there has been no research that analyzes the relationship
between individuals characteristic and the behavior of the Covid-19 pandemic in Bali. This
research is a cross sectional observation located in Gulingan Village. The research subjects
were 120 people aged 13-56 years who were selected by simple random sampling. The
level of obedience behavior towards Covid-19 was assessed using a questionnaire. The
collected data will be analyzed in univariate and bivariate ways. The subjects of this study
were dominated by respondents aged $\geq 19$ years (60\%), female gender (52.5\%), college
(50\%), student / college student (72.5\%), low risk of infection status (95.8\%), good
obedience behavior level (52.5\%). There is a significant relationship between gender and
the level of behavior regarding Covid-19, but there is no significant relationship between
age, education, occupation, and risk status on obedience behavior to Covid-19. Almost
every individual has a relationship with behavior in facing Covid-19 due to various factors.
Commitment to awareness, perception, and knowledge about health in each individual can
influence good behavior in preventing Covid-19. Obedient behavior implementing health
protocols is the key to prevent the transmission of Covid-19 transmission. This study shows
a significant relationship between gender and behavior regarding the Covid-19 pandemic
but not with age, education, occupation, and risk status.

\begin{tabular}{l}
\multicolumn{1}{c}{ ARTICLE INFO } \\
\hline Keywords: \\
Individual characteristics; Behavior; \\
Covid-19; Gulingan village
\end{tabular}

\section{Pendahuluan}

Dunia saat ini sedang dihadapi oleh virus berbahaya dengan tingkat mortalitas yang tinggi sejak akhir Desember 2019 yang pertama kali ditemukan di daerah Wuhan, China. Awalnya kasus tersebut dianggap sebagai pneumonia yang penyebabnya belum diketahui dengan kasus yang terus menambah tiap harinya. Berdasarkan pemeriksaan isolat pasien, ditemukan corona virus jenis baru yaitu SARS-CoV-2 virus dengan nama penyakit corona virus disease 2019 (Covid-19). Perkembangan kasus ini terus bertambah dari hari ke hari hingga penyebarannya semakin meluas ke negara lain. Hingga akhirnya World Health Organization (WHO) menetapkan bahwa Covid-19 merupakan pandemi dunia pada tanggal 11 Maret 2020 (1). Secara umum, tanda dan gejala Covid-19 berupa gangguan pernapasan akut seperti batuk, demam, dan sesak napas. Pada kasus Covid-19 yang berat, dapat ditemukan adanya pneumonia, sindrom pernapasan akut, gagal ginjal, hingga kematian. Penyakit ini memiliki masa inkubasi selama 5-6 hari dengan masa inkubasi terlama yaitu 14 hari (2).

Indonesia melaporkan kasus pertamanya pada tanggal 2 Maret 2020. Hingga saat ini angka kejadian terus meningkat dan membuat prevalensi Covid-19 di Indonesia tergolong sangat tinggi (2). Terhitung hingga 6 Oktober 2020, telah terdapat sebanyak 311.176 kasus terkonfirmasi positif, angka kesembuhan mencapai 236.437 orang, dan angka mortalitas sebanyak 11.374 orang (3). Tingginya prevalensi tersebut dapat disebabkan oleh mudahnya penyebaran corona virus yang dapat melalui droplet baik dari hidung mau pun mulut dari seseorang yang sudah terinfeksi Covid-19. Tidak hanya itu, penularannya juga dapat bersifat tidak langsung apabila droplet penderitanya menempel pada benda yang kemudian seseorang menyentuhnya dan mengarahkannya ke area mata, hidung, atau mulut (4).

Tindakan pencegahan terhadap pandemi Covid-19 dapat dilakukan dengan melaksanakan perilaku hidup bersih dan sehat (PHBS). Hal tersebut dapat berupa mencuci tangan yang baik dan benar, menerapkan etika batuk, menjaga jarak/physical distancing, serta menjaga higienitas tubuh (5). Upaya pencegahan lainnya dapat berupa pemberian edukasi kepada seluruh lapisan masyarakat mengenai Covid-19 melalui media yang dapat dijangkau oleh masyarakat seperti 
media sosial atau media online. Pemberian informasi edukatif dengan metode yang inovatif akan memberikan pengetahuan kepada masyarakat mengenai perilaku yang benar dalam mengatasi Covid-19. Pemutusan rantai transmisi Covid-19 ini adalah cara pencegahan penyakit yang paling efektif. Oleh karena itu, pencegahan Covid-19 harus difokuskan pada perilaku masyarakat dalam menanggapi pandemi ini (6).

Setiap lapisan masyarakat harus mampu untuk mengimplementasikan perilaku yang benar dalam mengahadapi Covid-19. Perilaku preventif yang tidak benar akan membuat peningkatan terhadap angka kejadian Covid-19. Perilaku masyarakat krusial untuk ditindaklanjuti karena saat ini belum ada terapi definitif ditambah dengan transmisi penularan yang amat mudah dan semakin meningkatnya kasus kejadian tiap harinya (7). Penyuluhan mengenai perilaku yang benar dalam menghadapi Covid-19 harus dapat dicapai oleh seluruh masyarakat. Seluruh lapisan masyarakat dapat mempraktikkan PHBS dalam kehidupan sehari-hari. Nyatanya, masih banyak masyarakat yang tidak taat terhadap protokol kesehatan karena masih ada masyarakat yang menganggap bahwa PHBS ini tidak penting dilakukan. Perilaku hidup bersih dan sehat memanglah sederhana, namun efektif untuk melawan Covid-19 apabila dilakukan (6).

Penyebaran virus corona yang semakin tinggi harus diimbangi oleh perilaku yang benar mengenai Covid-19 di tiap daerah. Bali merupakan salah satu dari sepuluh besar provinsi di Indonesia dengan angka kejadian Covid-19 yang tinggi. Terhitung pada 5 Oktober 2020, terdapat 9.448 kasus terkonfirmasi positif, 7.943 kasus sembuh, dan angkat mortalitas sebanyak 295 orang (3). Badung yang merupakan salah satu kabupaten di Bali menyumbang angka sebesar 1.525 kasus terkonfirmasi positif dan terdapat 36 orang yang meninggal dunia. Tingginya angka kejadian kasus Covid-19 di Badung membuatnya menduduki peringkat kedua setelah Kota Denpasar terhadap kasus Covid-19 (8). Salah satu desa yang berdomisili di Kabupaten Badung adalah Desa Gulingan. Desa Gulingan sudah memiliki beberapa kasus positif dan bahkan sempat menutup pelayanan kesehatan karena petugas kesehatannya terdampak oleh transmisi Covid-19.

Melihat adanya kasus positif yang tinggi, maka masyarakat harus mampu melawan pandemi ini dengan berperilaku yang benar sebagai langkah prevensi terhadap Covid-19. Hal tersebut harus mampu dilakukan oleh seluruh lapisan masyarakat baik dari seluruh usia, jenis kelamin, pekerjaan, tingkat pendidikan, dan lain-lain. Hingga saat ini belum ada penelitian yang menganalisis hubungan antara karakteristik individu terhadap perilaku masyarakat terhadap pandemi Covid-19 di Bali. Oleh karena itu, penulis ingin meneliti mengenai hubungan karakteristik individu dengan perilaku terhadap pandemi Covid-19 di Desa Gulingan, Mengwi, Badung.

\section{Metode Penelitian}

Penelitian ini merupakan penelitian analitik dengan rancangan potong lintang yang dilangsungkan di Desa Gulingan, Mengwi, Badung dengan tujuan untuk mengetahui hubungan karakteristik individu dengan perilaku mengenai pandemi Covid-19. Penelitian ini berlangsung selama lima bulan yang dimulai dari penyusunan proposal, pelaksanaan penelitian, pengumpulan dan pengolahan data, serta pembuatan laporan hasil penelitian. Populasi pada penelitian ini adalah warga Desa Gulingan yang dikunjungi saat pengumpulan data melalui kuesioner. Ada pun kategori inklusi sampel penelitian ini meliputi seluruh warga Desa Gulingan yang bersedia menjadi responden penelitian dengan menandatangi informed consent. Pemilihan sampel didasarkan atas metode simple random sampling yang melibatkan subjek yang tergolong dalam kategori inklusi. Besar sampel yang diperoleh berdasarkan rumus dua proporsi kelompok independen adalah minimal sebesar 53 subjek, sementara dalam penelitian ini diperoleh 120 orang sebagai sampel.

Pengumpulan data penelitian ini meliputi karakteristik individu seperti usia, jenis kelamin, tingkat pendidikan terakhir, pekerjaan (variabel independent), dan perilaku masyarakat terhadap pandemi Covid-19 (variabel dependent). Tingkat perilaku masyarakat akan terbagi 
menjadi dua yaitu ketaatan protokol kesehatan baik dan buruk. Data merupakan jawaban dari subjek penelitian melalui kuisioner dengan tujuh pertanyaan mengenai perilaku terhadap pandemi Covid-19.

Proses pengambilan sampel oleh peneliti disertai oleh protokol kesehatan lengkap dan dimulai dengan pemberian penjelasan terkait penelitian dan pembahasan mengenai informed consent. Peserta yang bersedia mengikuti penelitian wajib menandatangani informed consent tersebut. Kemudian peserta akan mengisi data dengan memberikan jawaban pada lembar kuesioner. Jawaban peserta penelitian yang terkumpul akan dihitung berdasarkan skoring. Keseluruhan data yang telah terkumpul akan dianalisis dengan metode univariat dan bivariat menggunakan bantuan perangkat lunak analisis data. Analisis data tersebut dimaksudkan untuk melihat gambaran distribusi dari masing-masing variabel baik variabel dependen maupun variabel independen. Analisis data bivariat ditujukan untuk mengetahui korelasi atau hubungan antara variabel dependen dan variabel independen. Uji normalitas data dilakukan dengan uji Kolmogorov-Smirnov yang kemudian dilanjutkan dengan uji chi-square.

\section{Hasil Penelitian}

Subjek penelitian dikategorikan berdasar usia, jenis kelamin, pendidikan terakhir, dan pekerjaan yang disajikan dalam tabel 1 . Usia subjek penelitian diperoleh berdasar selisih tanggal pengambilan data dengan tanggal lahir responden. Subjek penelitian ini terdiri dari 120 warga desa Gulingan dengan rentang usia 13-56 tahun. Karakteristik subjek penelitian berdasarkan usia didapatkan usia minimum adalah 13 tahun sementara usia maksimum adalah 56 tahun. Berdasarkan jenis kelamin subjek penelitian, didapatkan bahwa subjek penelitian didominasi oleh perempuan sebagai 63 orang dengan presentasi 52,5\% sementara laki-laki sebanyak 57 orang dengan presentasi 47,5\%. Karakteristik pendidikan terakhir subjek penelitian didominasi oleh jenjang perguruan tinggi sebanyak 60 orang dengan presentase $50 \%$, diikuti oleh jenjang SMA/Sederajat sebanyak 59 orang dengan presentase 49,2\%, serta jenjang SMP/Sederajat sebanyak 1 orang dengan presentase $0,8 \%$. Dilihat dari jenis pekerjaan subjek penelitian, terdapat 4 orang responden bekerja sebagai pegawai negeri sipil dengan presentase 3,3\%, 17 orang bertindak sebagai pegawai swasta dengan presentase 14,2\%, 87 orang bekerja sebagai siswa/mahasiswa dengan presentase $72,5 \%$, serta pekerjaan lainnya sebanyak 12 orang dengan presentase 10\%. Selain itu, mayoritas warga Desa Gulingan juga memiliki status risiko rendah terhadap Covid-19 yaitu sebesar 95.8\%, sedangkan risiko sedang hanya sebesar 2,5\%, dan didapatkan status OTG sebesar 1,7\%.

Tabel 1. Karakteristik Responden Penelitian

\begin{tabular}{|c|c|c|}
\hline \multirow[t]{2}{*}{ Keterangan } & \multicolumn{2}{|c|}{ Sampel $(n=120)$} \\
\hline & Frekuensi (n) & Persentase (\%) \\
\hline Usia Pasien & & \\
\hline Mean $\pm S D$ & $20.72 \pm 6.25$ & \\
\hline Minimum & 13 & \\
\hline Maximum & 56 & \\
\hline Jenis Kelamin & & \\
\hline Laki-Laki & 57 & 47.5 \\
\hline Perempuan & 63 & 52.5 \\
\hline Pendidikan Terakhir & & \\
\hline Perguruan Tinggi & 60 & 50 \\
\hline SMA/Sederajat & 59 & 49.2 \\
\hline SMP/Sederajat & 1 & 0.8 \\
\hline Pekerjaan & & \\
\hline Pegawai Negeri Sipil & 4 & 3.3 \\
\hline Pegawai Swasta & 17 & 14.2 \\
\hline Siswa/Mahasiswa & 87 & 72.5 \\
\hline Lainnya & 12 & 10 \\
\hline
\end{tabular}

Status Risiko Infeksi Covid-19 
Made Sindy Astri Pratiwi, Made Violin Weda Yani, Agus Indra Yudhistira Diva Putra, I Wayan Gita Mardiana, I Komang Ari Adnyana, Nyoman Manik Mas Genitri Putri, Ni Putu Sri Widi Adnyani Karang, \& I Putu Yudhi Setiawan: Hubungan karakteristik individu terhadap perilaku mengenai pandemi covid-19 di Desa Gulingan, Mengwi, Bali. Jurnal Kesehatan. Vol 13 (2) 2020

\begin{tabular}{lcc} 
Risiko Rendah & 115 & 95.8 \\
Risiko Sedang & 3 & 2.5 \\
OTG & 2 & 1.7 \\
\hline
\end{tabular}

Frekuensi distribusi sampel disajikan dalam tabel 2 yang terdiri dari data tingkat perilaku Covid-19. Dari 120 subjek penelitian, ketaatan untuk menjalankan protokol kesehatan terhadap pandemi Covid-19 lebih banyak dibanding dengan individu dengan tingkat ketaatan yang buruk. Responden dengan tingkat ketaatan baik yaitu sebesar $52,5 \%$ atau sebanyak 63 orang dan tingkat pengetahuan buruk sebesar $47,5 \%$ atau sebanyak 47 orang.

Tabel 2. Tingkat Ketaatan Perilaku mengenai Covid-19

\begin{tabular}{lcc}
\hline \multicolumn{1}{c}{ Keterangan } & \multicolumn{2}{c}{ Sampel (n=120) } \\
\cline { 2 - 3 } & Frekuensi (n) & Persentase (\%) \\
\hline Ketaatan Protokol Kesehatan & 63 & 52.5 \\
Baik & 47 & 47.5 \\
Buruk & & \\
\hline
\end{tabular}

Hasil tabulasi silang antara variabel karakteristik individu dengan tingkat perilaku terhadap pandemi Covid-19 dapat dilihat pada tabel 3. Hasil uji chi-square menunjukkan tidak adanya hubungan yang signifikan antara usia dengan perilaku ketaatan mengenai pandemi Covid-19 di Desa Gulingan ( $p$ value $=0.079 ; p>0.05$ ). Responden dengan usia $\geq 19$ tahun cenderung memiliki ketaatan yang baik mengenai Covid-19 dengan angka sebanyak 43 orang dengan presentase $59,7 \%$ sementara kategori buruk terdapat sebanyak 29 orang dengan presentase $40,3 \%$. Responden dengan usia $<19$ tahun memiliki presentase yang didominasi oleh ketaatan yang buruk terhadap protokol kesehatan dengan angka sebesar 58,3\% atau sebanyak 28 orang sementara yang memiliki perilaku taat yang baik adalah sebesar $41,7 \%$ atau sebanyak 20 orang.

Apabila ditinjau dari karakteristik jenis kelamin responden, didapatkan pula adanya hubungan yang signifikan antara jenis kelamin dengan tingkat perilaku mengenai Covid-19 ( $p$ value= 0.007; $p<0.05$ ). Pada jenis kelamin laki-laki, sebanyak 22 orang memiliki perilaku yang baik terhadap Covid-19 dengan presentase sebesar 38,6\% sementara 35 orang memiliki perilaku ketaatan yang buruk terhadap Covid-19 dengan presentase sebesar 61,4\%. Di sisi lain, mayoritas perempuan memiliki tingkat perilaku yang baik terhadap Covid-19 dengan jumlah sebanyak 41 orang dengan presentase $65,1 \%$ sementara yang memiliki ketaatan yang buruk adalah sebanyak 22 orang dengan presentase $34,9 \%$.

Berdasarkan pendidikan terakhir responden dengan hasil uji chi-square, tidak ditemukan adanya hubungan yang signifikan antara pendidikan terakhir responden terhadap tingkat pengetahuan mengenai Covid-19 ( $p$ value $=0.465 ; p>0.05$ ). Responden dengan pendidikan tinggi memiliki tingkat ketaatan baik sebesar 34 orang dengan presentase 56,7\% sementara yang memiliki tingkat ketaatan buruk terdapat sebanyak 26 orang dengan presentase sebesar $43,3 \%$. Sementara itu, responden dengan pendidikan menengah didominasi oleh tingkat ketaatan buruk sebanyak 31 orang dengan presentase 51,7\% dan yang memiliki tingkat ketaatan baik sebesar 29 orang dengan presentase $48,3 \%$.

Hasil yang tidak signifikan terhadap tingkat perilaku protokol kesehatan Covid-19 juga didapatkan pada karakteristik individu yang ditinjau dari jenis pekerjaannya ( $p$ value $=0.060$; $p>0.05)$. Responden dengan pekerjaan sebagai pegawai swasta dan negeri didominasi dengan perilaku yang baik dengan angka 14 orang dengan presentase sebesar $66,7 \%$ sementara dengan perilaku yang buruk didapatkan sebanyak 7 orang dengan presentase $33,3 \%$. Melihat pekerjaan lain yaitu siswa/mahasiswa, sebanyak 40 orang dengan presentase $46 \%$ memiliki tingkat perilaku yang baik terhadap protokol kesehatan Covid-19 sementara 47 orang dengan presentase 54\% memiliki perilaku yang buruk mengenai protokol kesehatan Covid-19. Responden dengan pekerjaan lainnya juga didominasi dengan perilaku yang baik sebesar 9 orang dengan presentase $75 \%$ diikuti dengan 3 orang yang memiliki perilaku buruk terhadap Covid-19 dengan presentase sebesar $25 \%$. 
Karakteristik individu juga menilai mengenai status risiko responden terinfeksi Covid-19. Responden yang memiliki status resiko rendah terkena Covid-19 memiliki mayoritas berperilaku baik sebanyak 62 orang dengan presentase 53,9\% sementara yang berperilaku buruk sebanyak 53 orang dengan presentase $46,1 \%$. Responden dengan status risiko sedang terkena Covid-19 seluruhnya cenderung memiliki perilaku yang buruk mengenai Covid-19 dengan presentase 66,7\% pada 2 orang dan sebanyak 1 orang dengan presentase $33,3 \%$ taat terhadap protokol kesehatan. Hal serupa juga didapatkan pada responden yang berstatus OTG yang terdiri atas 2 orang dengan presentase 100\% cenderung memiliki perilaku ketaatan yang buruk.

Tabel 3. Hubungan Karakteristik Individu Terhadap Perilaku Mengenai Covid-19

\begin{tabular}{lccc}
\hline \multicolumn{1}{c}{ Karakteristik Individu } & \multicolumn{2}{c}{ Perilaku Taat } & \multirow{2}{*}{ P Value } \\
\cline { 2 - 3 } & \multicolumn{1}{c}{$\begin{array}{c}\text { Baik } \\
\text { n (\%) }\end{array}$} & $\begin{array}{c}\text { Buruk } \\
\text { n (\%) }\end{array}$ & \\
\hline Usia & $43(59.7 \%)$ & $29(40.3 \%)$ & $0.079^{*}$ \\
$\geq 19$ tahun & $20(41.7 \%)$ & $28(58.3 \%)$ & \\
$<19$ tahun & $22(38.6 \%)$ & $35(61.4 \%)$ & $0.007^{*}$ \\
\hline $\begin{array}{l}\text { Jenis Kelamin } \\
\text { Laki-Laki }\end{array}$ & $41(65.1 \%)$ & $22(34.9 \%)$ & \\
Perempuan & $34(56.7 \%)$ & $26(43.3 \%)$ & $0.465^{*}$ \\
\hline $\begin{array}{l}\text { Pendidikan Terakhir } \\
\text { Pendidikan Tinggi }\end{array}$ & $29(48.3 \%)$ & $31(51.7 \%)$ & \\
Pendidikan Menengah & $14(66.7 \%)$ & $7(33.3 \%)$ & $0.060^{*}$ \\
\hline $\begin{array}{l}\text { Pekerjaan } \\
\text { Pegawai Negeri\&Swasta }\end{array}$ & $40(46.0 \%)$ & $47(54.0 \%)$ & \\
$\begin{array}{l}\text { Siswa/Mahasiswa } \\
\text { Lainnya }\end{array}$ & $9(75.0 \%)$ & $3(25.0 \%)$ & \\
\hline Status Risiko Infeksi & & & \\
Risiko Rendah & $62(53.9 \%)$ & $53(46.1 \%)$ & $0,254^{*}$ \\
Risiko Sedang & $1(33.3 \%)$ & $2(66.7 \%)$ & \\
OTG & $0(0 \%)$ & $2(100 \%)$ & \\
\hline
\end{tabular}

\#Uji Chi-Square; * $p$ value $<0.05$.

\section{Diskusi}

Sebanyak 120 subjek penelitian yaitu warga Desa Gulingan berusia 13-56 tahun mengikuti penelitian ini. Frekuensi terbesar yaitu pada usia $\geq 19$ tahun. Pada penelitian ini didapatkan bahwa individu yang berusia $\geq 19$ tahun mayoritas memiliki perilaku taat protokol kesehatan Covid-19 dibanding dengan individu berusia $<19$ tahun yang mayoritasnya memiliki perilaku taat yang buruk. Penelitian ini menunjukkan hubungan yang tidak signifikan antara usia dengan ketaatan seseorang terhadap protokol kesehatan Covid-19. Hal ini dapat disebabkan oleh tingkat kedisiplinan masing-masing individu. Individu yang berusia lebih muda cenderung masih berada pada tahap pengembangan sikap disiplin dalam mengikuti protokol kesehatan yang juga dipengaruhi oleh komitmen kesadaran pada dirinya (9). Selain itu, individu dengan usia muda lebih membutuhkan pendampingan dalam menerapkan perilaku hidup bersih dan sehat melawan pandemi Covid-19. Keterbatasan informasi yang didapatkan, membuat mereka memerlukan bimbingan oleh orang dewasa untuk dapat menerapkan protokol kesehatan melawan Covid-19 (10).

Pada penelitian ini, didapatkan bahwa jenis kelamin perempuan cenderung lebih taat melakukan protokol kesehatan dibanding dengan jenis kelamin laki-laki. penelitian ini juga menemukan adanya hubungan yan signifikan antara jenis kelamin dengan perilaku ketaatan terhadap protokol kesehatan. Penelitian serupa oleh Zhong pada tahun 2020 di China mengungkapkan bahwa individu yang berjenis kelamin laki-laki memiliki risiko 1,37 kali lebih tinggi memiliki perilaku yang tidak baik terhadap protokol kesehatan karena cenderung 
bepergian ke tempat ramai dan tidak menggunakan masker di luar apabila dibandingkan dengan individu berjenis kelamin perempuan (11).

Apabila ditinjau dari tingkat pendidikan responden, penelitian ini tidak mendapatkan hubungan yang signifikan antara pendidikan dengan perilaku mengenai Covid-19. Tingkat pendidikan pada dasarnya adalah salah satu faktor yang memengaruhi tingkat pengetahuan seseorang dan tidakan masyarakat karena pengetahuan akan langsung berpengaruh pada perilaku disebabkan adanya Pendidikan (12). Adanya hubungan yang tidak signifikan antara tingkat pendidikan dengan perilaku mengenai Covid-19 dapat dipengaruhi oleh beberapa komponen yang dapat mengeksplorasi perilaku seseorang seperti perbedaan persepsi mengenai kerentanan penyakit, persepsi dalam upaya pencegahan, persepsi tentang manfaat, serta persepsi individu tersebut untuk melakukan upaya pencegahan (13).

Lingkungan pekerjaan dapat memberikan pengetahuan atau pengalaman kepada seseorang baik secara langsung atau pun tidak yang juga akan memengaruhi proses seseorang untuk mencerna pengetahuan (14). Pada penelitian ini tidak ditemukan adanya hubungan yang signifikan antara pekerjaan dengan perilaku ketaatan dalam menjalankan protokol kesehatan. Hasil serupa juga ditemukan pada penelitian Prihati dkk pada tahun 2020 yang juga mendapatkan hubungan yang tidak signifikan antara pekerjaan dengan perilaku dalam pencegahan Covid-19 (15). Seseorang yang bekerja dalam lingkup kesehatan akan memiliki pengetahuan kesehatan yang lebih tinggi daripada yang tidak karena pengalaman yang dijalaninya (16). Namun, apabila dikaitkan dengan penelitian Wulandari pada tahun 2020, status pekerjaan tidak memiliki korelasi yang signifikan dengan pengetahuan Covid-19 karena proporsi tingkat pengetahuan rendah yang sama antara individu yang bekerja dan yang tidak bekerja (17).

Status risiko terhadap Covid-19 akan lebih berbahaya dan risiko komplikasi yang lebih tinggi pada penduduk yang berusia rentan, individu yang memiliki kelemahan, dan mengalami kondisi kronis (18). Dikatakan bahwa usia yang lebih muda akan memiliki risiko yang lebih rendah terhadap pandemi Covid-19, namun isolasi dapat membuat gagal memahami, ketakutan, dan kebingungan sehingga ia harus berkompromi terhadap perilaku dalam menghadapi Covid-19 (19). Penelitian ini mendapatkan hasil yang tidak signifikan antara status risiko terhadap ketaatan seseorang melawan Covid-19. Hal ini dapat disebakan oleh kemampuan Covid-19 memiliki daya tular yang sangat mudah dan berbeda dibanding dengan virus lainnya. Studi menyebutkan bahwa semua orang berisiko karena penyebarannya dapat melalui percikan droplet yang ukurannya sangat kecil dari orang yang terinfeksi (20).

Penularan yang cepat, kasus mortalitas yang tidak dapat diabaikan, serta belum adanya terapi definitif membuat kasus Covid-19 ini harus diwaspadai (21). Menjaga kebersihan tangan dengan mencuci tangan apabila tangan terlihat kotor atau menggunakan handsantizer apabila tidak terlihat kotor, menjaga jarak minimal satu meter dari orang lain, memakai masker, menjaga etika batuk dan bersin, menghindari menyentuh mata, hidung, mulut adalah perilaku yang dapat dilakukan untuk mencegah penularan Covid-19 sebagai kunci penerapan kesehatan masyarakat (22).

\section{Kesimpulan}

Berdasarkan penelitian yang dilangsungkan di Desa Gulingan, Kecamatan Mengwi, Kabupaten Badung yang melibatkan 120 warga desa tahun ini menunjukkan adanya hubungan yang signifikan antara jenis kelamin dengan perilaku mengenai pandemi Covid-19 namun tidak dengan usia, pendidikan, pekerjaan, dan status risiko.

\section{Daftar Pustaka}

1. Li Q, Guan X, Wu P, Wang X, Zhou L, Tong Y, Ren R, Leung KS, Lau EH, Wong JY, Xing X. Early transmission dynamics in Wuhan, China, of novel coronavirus-infected pneumonia. New England Journal of Medicine. 2020. 
2. Kementerian Kesehatan RI. Pedoman Pencegahan dan Pengendalian Coronavirus Disease (Covid-19). 2020.

3. Gugus Tugas Percepatan Penanganan COVID-19. Peta Sebaran. 2020

4. Athena A, Laelasari E, Puspita T. Pelaksanaan Disinfeksi Dalam Pencegahan Penularan Covid-19 Dan Potensi Risiko Terhadap Kesehatan Di Indonesia. Jurnal Ekologi Kesehatan. 2020 Jun 25;19(1):1-20.

5. Razi F, Yulianty V, Amani, SA, Fauzia JH. Bunga Rampai COVID-19: Buku Kesehatan Mandiri untuk Sahabat. PD Prokami: Depok. 2020.

6. Karo MB. Perilaku Hidup Bersih dan Sehat (PHBS) Strategi Pencegahan Penyebaran Virus Covid-19. InProsiding Seminar Nasional Hardiknas 2020 May 30;1:1-4.

7. Wulandari A, Rahman F, Pujianti N, Sari AR, Laily N, Anggraini L, \& Prasetio D. B. Hubungan Karakteristik Individu dengan Pengetahuan tentang Pencegahan Coronavirus Disease 2019 pada Masyarakat di Kalimantan Selatan. Jurnal Kesehatan Masyarakat Indonesia. 2020;15(1), 42-46.

8. Dinas Kesehatan Provinsi Bali. Data Sebaran Kasus Covid-19 Sampai dengan Tanggal 202010-07 di Bali. 2020.

9. Purandina IP, Winaya IM. Pendidikan Karakter di Lingkungan Keluarga Selama Pembelajaran Jarak Jauh pada Masa Pandemi COVID-19. Cetta: Jurnal Ilmu Pendidikan. 2020 Jun 25;3(2):270-90.

10. Zukmadini AY, Karyadi B, Kasrina K. Edukasi Perilaku Hidup Bersih dan Sehat (PHBS) dalam Pencegahan COVID-19 Kepada Anak-Anak di Panti Asuhan. Jurnal Pengabdian Magister Pendidikan IPA. 2020 Jul 17;3(1).

11. Zhong BL, Luo W, Li HM, Zhang QQ, Liu XG, Li WT, Li Y. Knowledge, attitudes, and practices towards COVID-19 among Chinese residents during the rapid rise period of the COVID-19 outbreak: a quick online cross-sectional survey. International journal of biological sciences. 2020;16(10):1745.

12. Dharmawati IG, Wirata IN. Hubungan tingkat pendidikan, umur, dan masa kerja dengan tingkat pengetahuan kesehatan gigi dan mulut pada guru penjaskes sd di Kecamatan Tampak Siring Gianyar. Jurnal Kesehatan Gigi. 2016;4(1).

13. Almi.(2020).https://almi.or.id/2020/06/05/analisis-penyebab-masyarakat-tidak-patuhpada-protokol-covid-19/diakses28Juni2020

14. Mubarak, W. Promosi Kesehatan untuk Kebidanan. Jakarta: Salemba Medika.2011.

15. Prihati DR, Wirawati MK, Supriyanti E. Analisis Pengetahuan Dan Perilaku Masyarakat Di Kelurahan Baru Kotawaringin Barat Tentang Covid 19. Malahayati Nursing Journal. 2020 Sep 1;2(4):780-90.

16. Notoatmodjo S. Ilmu Perilaku Kesehatan. 2nd ed. Jakarta: Rineka Cipta. 2014.

17. Syakurah RA, Moudy J. Pengetahuan terkait Usaha Pencegahan Coronavirus Disease (COVID-19) di Indonesia. HIGEIA (Journal of Public Health Research and Development). 2020 Jul 29;4(3):333-46.

18. DeCaprio D, Gartner J, Burgess T, Kothari S, Sayed S. Building a COVID-19 vulnerability index. arXiv preprint arXiv:2003.07347. 2020 Mar 16.

19. Vessey JA, Betz CL. Everything old is new again: COVID-19 and public health. Journal of Pediatric Nursing. 2020 May;52:A7.

20. Jin YH, Cai L, Cheng ZS, Cheng H, Deng T, Fan YP, Fang C, Huang D, Huang LQ, Huang Q, Han Y. A rapid advice guideline for the diagnosis and treatment of 2019 novel coronavirus (2019-nCoV) infected pneumonia (standard version). Military Medical Research. 2020 Dec 1;7(1):4.

21. Susilo A, C. Martin Rumende, Ceva W Pitoyo, Widayat Djoko Santoso, Mira Yulianti, Herikurniawan, Robert Sinto, Gurmeet Singh, Leonard Nainggolan, Erni J Nelwan, Lie Khie Chen, Alvina Widhani, Edwin Wijaya, Bramantya Wicaksana, Maradewi Maksum, Firda Annisa, Chyntia OM Jasirwan, Evy Yunihastuti. Coronavirus Disease 2019. Jurnal Penyakit Dalam Indonesia 2020; 7(1): 45-67. 
Made Sindy Astri Pratiwi, Made Violin Weda Yani, Agus Indra Yudhistira Diva Putra, I Wayan Gita Mardiana, I Komang Ari Adnyana, Nyoman Manik Mas Genitri Putri, Ni Putu Sri Widi Adnyani Karang, \& I Putu Yudhi Setiawan: Hubungan karakteristik individu terhadap perilaku mengenai pandemi covid-19 di Desa Gulingan, Mengwi, Bali. Jurnal Kesehatan. Vol 13 (2) 2020

22. Direktorat Jenderal Pencegahan dan Pengendalian Penyakit (P2P). Pedoman Pencegahan dan Pengendalian Coronavirus Disesase (Covid-19). Jakarta: Kementerian Kesehatan RI. 2020. 


\title{
KOMISI ETIK PENELITIAN (KEP)
}

\section{FAKULTAS KEDOKTERAN UNIVERSITAS UDAYANA/}

\section{RUMAH SAKIT UMUM PUSAT SANGLAH DENPASAR}

Jalan P. Serangan Denpasar Bali (80114) Telp. (0361) 227911-15 (P.227), (0361) 244534

\author{
KETERANGAN KELAIKAN ETIK \\ (ETHICAL CLEARANCE)
}

NO:1925/UN14.2.2.VII.14/LT/2020

Komisi Etik Penelitian Fakultas Kedokteran Universitas Udayana/Rumah Sakit Umum Pusat Sanglah Denpasar, setelah mempelajari dengan seksama rancangan penelitian yang diusulkan dengan ini menyatakan bahwa penelitian dengan judul :

"HUBUNGAN KARAKTERISTIK INDIVIDU TERHADAP PERILAKU MENGENAI PANDEMI COVID-19 DI DESA GULINGAN, MENGWI, BALI"

Peneliti Utama

: Made Sindy Astri Pratiwi

Peneliti Lain
: 1. Made Violin Weda Yan
2. Agus Indra Yudhistira Diva Putra
3. I Wayan Gita Mardiana
4. I Komang Ari Adnyana
5. Nyoman Manik Mas Genitri Putri
6. Ni Putu Sri Widi Adnyani Karang
7. I Putu Yudhi Setiawan

Unit/Lembaga/Tempat Penelitian : Desa Gulingan, Mengwi, Bali

Nomor

: 2020.01.1.0802

Dinyatakan Laik Etik. Surat Keterangan ini berlaku selama satu tahun sejak ditetapkan. Adapun jenis laporan yang harus disampaikan kepada komisi etik :

Progress report setiap.......... bulan

Final report

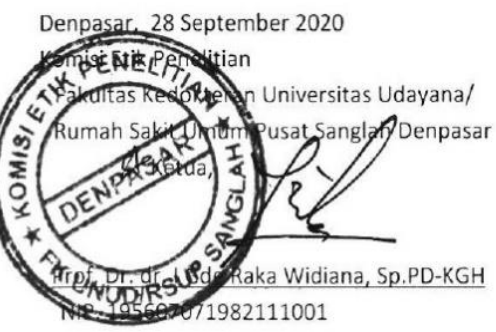

